\title{
18. Limited Preferential Voting in Enga: The Wabag Open Electorate
}

\author{
Philip Gibbs ${ }^{1}$
}

Politics in Enga Province is known for its intensity and sometimes violence. I have written previously about the 'political culture' that has emerged (Gibbs 2004, 2006). It is a culture which draws on traditions, but adapts to modern realities.

The previous election in 2002 did not go well in Enga. The polling began a week later than planned and was drawn out for two weeks in a drama involving hijacked ballot boxes, the bombing of voting papers in containers beside the Wabag Police Station, and fatal shootings at one polling place (The National 12-14 July 2002:1-2; Independent 1 August 2002:2).

Following the 2002 election, Daniel Kapi successfully challenged Samuel Abal's win in the Wabag Open seat in the national and supreme courts. The ensuing 2004 by-election was the first in Enga to use the limited preferential voting (LPV) system, though the focus throughout the by-election remained on first preferences. Technically, Samuel Tei Abal won using preferences. However, he was well ahead across most of the electorate with the (38 percent) first preference vote and the primary vote lead ensured his victory (Gibbs 2006).

After a comparison with previous elections, this paper will consider issues from the campaign period, polling, and counting in the Wabag Open electorate (Figure 18.1) in the 2007 general election. Voting patterns and reasons behind those patterns will be treated in detail, followed by reflection on the implications for democracy in Enga. Of particular interest is how the LPV system has functioned, and how Enga political culture is managing the LPV system.

Data came from a study of the content of election campaign speeches, interviews with key persons and people 'on the street', observation of campaigning and polling, and the collation and analysis of polling results.

\footnotetext{
1 I wish to acknowledge the coordination of the National Research Institute and funding by AusAID through the Electoral Support Program, members of the Electoral Commission, particularly those in Wabag, the domestic observer team, and all those people in Enga and elsewhere who assisted in any way in the research for this paper.
} 


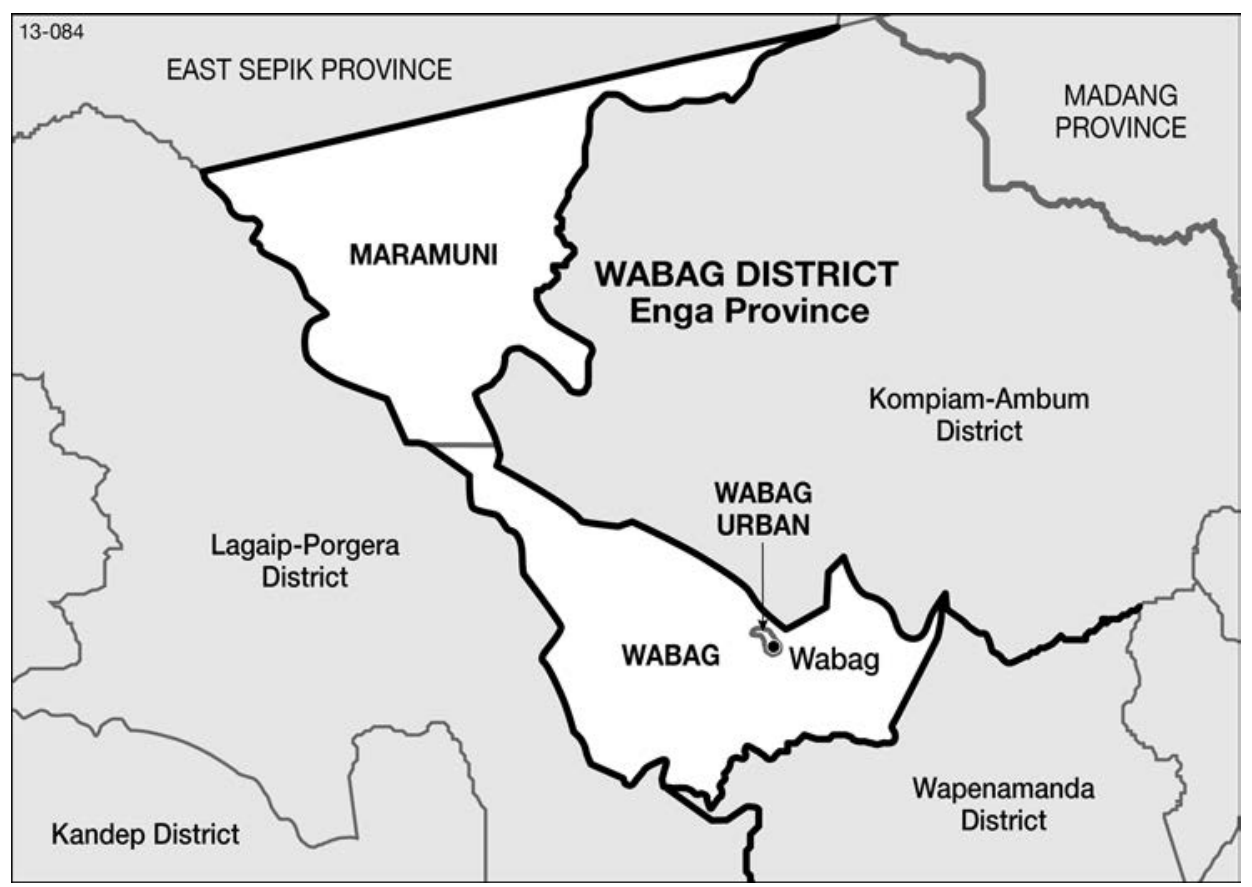

Figure 18.1: Wabag District

\section{Comparison with previous elections}

In the Wabag Open electorate in 2007 there were 19 candidates compared with 25 candidates five years previously. Of those 19, six had stood in the 2002 election and five in the 2004 by-election. Only two of these had stood before in both the 2002 and 2004 elections.

The election in 2007 saw a radical drop in the number of papers issued compared to 2002 and 2004 (Table 18.1), largely due to the creation of a new electoral roll. Also, in both 2004 and 2007, almost all ballot boxes were counted, unlike the situation in 2002 when containers at the Wabag Police Station were bombed.

Table 18.1: Wabag Open electorate: comparison 2002, 2004 and 2007

\begin{tabular}{lrrr}
\hline Issue & 2002 & $\mathbf{2 0 0 4}$ & $\mathbf{2 0 0 7}$ \\
\hline Number of candidates & 25 & 19 & 19 \\
Number of polling places & 72 & 64 & 66 \\
Ballot papers issued to polling places & 67,832 & 71,000 & 47,798 \\
Ballot papers counted & 51,002 & 53,867 & 44,689 \\
Ballot papers unused and returned or burned by officials & 4,178 & 17,133 & 3,109 \\
Ballot boxes destroyed or disputed and not counted & 13 & 0 & 1 \\
\hline
\end{tabular}


Despite the changes, the electoral roll in Enga still had serious deficiencies. In most cases the enrolment teams did not bring enrolment forms to the people, but filled in the forms themselves for both the initial enrolment and the verification. This meant that some people missed out. For example, my checking of the roll for the Lakemanda ward revealed that the names of 289 eligible voters were not on the roll. Nearly all these people thought their names were on the roll, and when it came to polling day and their names were absent there was a great deal of anger - so much so that they told the polling officials to take the ballot box back to Wabag and to return with a correct roll. Police and Papua New Guinea Defence Force personnel convinced them to vote the following day, but only with a lot of disruption from disgruntled clan members.

Despite the fact that some people claimed their names were not included, there was still a major inflation of the roll compared to projected figures from the year 2000 census (Table 18.2). Some names were missing, while at the same time inaccuracies inflated the roll, particularly names duplicated in different wards - for example, a woman whose name is recorded both with her husband's clan and also in another ward with her family of origin.

The late arrival of the electoral rolls in the last week of June meant that there was no time for last minute changes or corrections, since polling started on 3 July.

Table 18.2: Comparison of enrolment numbers over three elections in Enga

\begin{tabular}{|c|c|c|c|c|c|}
\hline $\begin{array}{l}\text { District name } \\
\text { (Open seat) }\end{array}$ & $\begin{array}{r}1997 \\
\text { enrolled }\end{array}$ & $\begin{array}{r}2000 \text { census } \\
18+\end{array}$ & $\begin{array}{r}2002 \\
\text { enrolled }\end{array}$ & $\begin{array}{r}\text { Estimated } \\
2007 \text { eligible } \\
\text { voters }\end{array}$ & $\begin{array}{r}2007 \\
\text { enrolled }\end{array}$ \\
\hline Kandep & & 25,058 & 49,122 & 28,500 & 42,318 \\
\hline Kompiam-Ambum & & 25,445 & 74,171 & 28,500 & 39,486 \\
\hline Lagaip-Porgera & & 51,206 & 135,587 & 57,500 & 95,006 \\
\hline Wabag & & 34,657 & 72,759 & 39,000 & 47798 \\
\hline Wapenamanda & & 2,892 & 79,564 & 36,000 & 49,785 \\
\hline Enga total & 267,728 & 169,258 & 411,203 & 189,500 & a 274,393 \\
\hline
\end{tabular}

a 45 percent over census estimate

\section{Campaign period}

The campaign period in Enga in 2007 was quieter than that of the 2002 election. There were few large rallies with public addresses, and candidates seemed to prefer smaller clan-level gatherings. The focus of our enquiry at this time was on the 19 candidates for the Wabag Open electorate. Except for the murder of 
a 'Rambo' (renowned gunman) at an election rally at Lenki (though the murder itself was not necessarily election-related) and a shooting incident at a rally on 9 June in Kandep (The National 19 June 2007:1-2) the campaign period was relatively peaceful in Enga. Bushknives and axes were seen at the rallies and during the campaign period, but not guns.

Generally, there was freedom of movement in the province during the campaign period. However, there was some disruption of roads. For example, people from the Piyao clan at Tole organized a rally for Samuel Tei Abal, but some of Daniel Kapi's supporters dug a drain across the road which stopped Abal from attending the rally and caused the rally to be postponed for several days. There was a lot of bad feeling about this in the clan. Some roads such as the Wabag to Sakarip highway were closed at times by people demanding the sitting members of parliament pay them for upgrading the roads.

\section{Rallies}

Election rallies are events where supporters of candidates can congregate to see how much support each candidate has. Rallies are organized by 'hot' candidates so as to see their supporters from different parts of the electorate in a procession to the grandstand. Rallies are also a time when 'local scientist' interpreters look for signs and interpret these signs to predict the future for the candidates involved.

In past elections, rallies were being held from the time campaigning started to the end of the campaigning period. In 2007, in the Wabag Open electorate there were only six rallies during the whole period. The change is probably an effect of the LPV voting system. Candidates fear that if they organize rallies, those voters who are planning to give their second and third preferences will come along with the ones who are coming to give their first preference and they will find it hard to distinguish how many first votes they will collect from the supporters. Many think it is a waste of resources to organize a rally just to get a few first preferences and more second and third preferences.

Popular themes in rally speeches were corruption and the use of public funds, lack of development in the province, and law and order. Candidates seldom mentioned the LPV system other than asking for first preferences (or in the case of Philip Neri, second preferences if people had already made up their minds about their first preference).

Some of the speeches were on topics that run quite contrary to the spirit of a free vote in a preferential voting system. For example, Pato Potane, in a rally at Lenki (22 June 2007) encouraged clan bloc voting: 'If any Dep, Lipin and 
Yakain votes for somebody else, that shows that you are insane. We can get this member because the governor is giving it to us and why not. Before we, the Yakains campaigned hard for governor and he won and now he formed the new party and he is going away to form the next government and he wants me to become caretaker for Enga'.

At another rally at Kamas (26 June 2007) Pato Potane, referring to family ties, encouraged people to vote along family lines. His wife comes from there, so in addressing his in-laws he said that this was a chance for them to vote for their 'sister' (meaning to vote for him who was married to their sister). He reinforced this argument with the following image: 'No fathers forsake their daughters and favour their sons. This is my land and thank you all my brothers and sisters-inlaw. I want to assure you that I have base votes from the Yakain, Lipin and Dep and I am sure I will win this election and become the acting governor so all my in-laws, please vote for me'.

Samuel Tei Abal in his campaigning focused less on tribal ties and more on party politics for gaining first preferences. At Kopen (26 June 2007) he praised the Somare government: 'The Somare government is likely to return to parliament and will take over the governing role again so I don't want to be left out. I am unlikely to join Ipatas because I don't want to be regarded as a yoyo by the people. I have a great interest in NA [the National Alliance party] and I encourage you to vote for me because I have done a lot for the electorate as well as the nation. Somare has accumulated funds of about K1.7 billion to save the country in the next five years, so I will be able to bring back to the people whatever portion of that amount would be given to me in terms of development'.

Some of the speech-making typically used metaphorical language which is fascinating yet hard to pin down to an exact meaning. For example, Philip Nere at Sari (25 June 2007) warned the Yapokon and Kalepetae clans that in listening to Daniel Kapi, 'You are swinging in a wild man's string bag' (meaning that they might vote for a person who would come to take their votes and disappear like a stranger). In an allusion to the darker side of politics he continued, 'I'll stay with you to do the marking and in the night I'll come and check the list with 1st and 2nd votes or else I'll press a button ...'

Through such speeches candidates try to attract votes using various strategies. Maintaining a 'base' vote with one's own clansmen and women is still essential. But with the LPV system, even more than before, it is important to exploit the opportunity for alliances. In some cases alliances based on links with clans who have more young warriors with high-powered firearms, or clans who have more members employed in the public and private sectors, overshadow traditional alliances maintained through intermarriage or pig exchange. 


\section{Awareness}

Election awareness by the Papua New Guinea Electoral Commission was limited and late. Materials, including candidate posters, arrived only a week before polling. In previous elections, awareness was taken up by civil society groups, particularly by Caritas through the Catholic Church network. This time, because a (suspended) Catholic priest was standing for the provincial seat, the Caritas awareness in Enga was very low key, since they were concerned that they might be seen as supporting the priest candidate. Of the awareness that was conducted, either by the electoral commission or civil society groups, the focus was on the mechanics of the new way of voting rather than on issues of governance or civics (rights and the meaning of democracy).

One of our observers commented, 'People hear about democratic elections but they don't really know what it means'. In fact, many leaders in Enga seem not interested in promoting a system of secret individual voting, as they stand to gain from the public group voting system which has become the norm in Enga electoral politics. If a few leaders decide who will receive the first preference of the clan as a whole, then what is the point of making people aware of an alternative system with individual secret voting?

\section{Parties and OLIPPAC}

It is hard to assess the impact of the electoral reforms: the Organic Law on the Integrity of Political Parties and Candidates (OLIPPAC), 2003, and the new form of LPV introduced in the August 2006 amendments to the Organic Law on National and Local-Level Government Elections.

OLIPPAC was supposed to strengthen political parties in election campaigning, voting and ultimately in the parliament and cabinet, in order to improve stability in governance. Parties did have a higher profile in the 2007 elections than in 2002. Support or opposition to the National Alliance party (NA) was significant, with supporters of Governor Peter Ipatas's People's Party opposing NA. It seemed that NA was well funded. The sitting member for Wabag Open had access to over a million kina through District Support Grant funds. Though a party could legally only endorse one candidate in each electorate, it was common knowledge that there were independents with close links to certain parties; for example, Maso Samai, who stood as an independent, was known to be an NA supporter.

LPV is designed to encourage candidates to seek preferences in each other's base areas, leading to more collaborative campaigning, and ultimately to the election 
of members of parliament with wider popular mandates. This was the case in Enga, though as will be shown below, the people generally did not appreciate the significance of second and third preferences, and in many cases did not have a chance to utilize those preferences anyway because of group rather than individual voting.

\section{Bribery and treating prior to polling}

Elections are a 'business' in Enga. Candidates with money go around or send some of their supporters around with money to buy first votes from clans and families. We heard of only a few candidates or their supporters buying second or third preferences - at least until the night before the polling. The night before polling, near Wabag, first preferences were selling for K100, and second or third preferences for K30 or K20. Money would go to individuals or, more often, to councillors or clan leaders.

There are various ways to gain favour other than with cash. Candidates also assisted with cars, food and drink, transporting bodies of the dead and contributing to funerary feasts. The sitting member for Wabag told people to 'clean' roads and then paid money for it through the District Roads Improvement Program (DRIP).

There does not appear to have been any policing of these practices during the 2007 election, despite police (and civil society) warnings about bribery. How would one distinguish between genuine assistance and unacceptable treating? Bribery and treating appear to be well embedded in Enga political culture; such practice is called maiyu neo (give and eat) according to the principle of reciprocity. After the 2002 election, those who supported losing candidates were called nanenge or 'non-eaters' (Gibbs and Lakane 2003). It seems that such gifting has a coercive dimension. When people found they could not vote at Lakemanda because their names were not on the roll, their complaints were not based on issues of franchise or democracy, but rather on the fact that they had taken money from a candidate and eaten his food and so were required to demonstrate on polling day that they were indeed giving their votes to him. In fact, LPV allows both candidates and voters to trade for three votes instead of only one.

\section{Polling}

Polling began on 3 July as planned. In most places polling commenced only in the afternoon of that day, so continued into 4 July, and for some outlying areas 
served by helicopters, such as Maramuni, it continued through to 9 July. There seemed to be a lot of confusion about transport and there was a bottleneck at the Wabag Primary School distribution centre with only one truck being allowed in at a time, thus further delaying the deployment of teams.

Individual secret voting was a rarity in Enga. In some cases people did fill in their own ballot papers, but seldom alone or in secret. In many cases people voted in family groups, with the head of a family claiming ballot papers for his or her 'family' and then a small group of family members filling in the papers. In other cases, papers were filled in by scrutineers or representatives of candidates. Throughout Maramuni the common practice was for clan leaders to recruit a few literate young men to mark all the ballot papers according to what the leaders decided, while the majority of the population had no part in the voting.

There was some serial voting - where people voted at different polling places (this is quite possible when there is 'split' voting for a ward, with copies of the same roll being used for several polling places, as happened at a number of locations in the Wabag Open electorate). People who voted more than once might also have had their names enrolled in two or more rest houses or voted on behalf of absentees.

At Tole, a candidate and his supporters had guns and controlled the voting so there was little say for the majority of the people of that resthouse. This practice was not acceptable to many members of the community. A person from Tole commented as follows:

I heard three gun shots in the morning of the polling day. X fired again during the midst of the signing of the ballot papers ... Actual polling took place on the next day and we tried to force him to leave the ballot papers and we would have secret polling but he never wanted to do so. Supporters of Potane, Kopamo and Sam got so mad that they marched in with bush knives and threatened to fight so he gave 250 to Kopamo, 30 to Potane and 30 to Sam. Ever since he started to contest in election, the Tole people have never exercised their democratic rights to vote a candidate. He has taken our rights away totally at gunpoint. He will never win any election because he robs his own people. All of us were looking forward to vote in the LPV system but it's a sad thing that we never did. This is injustice! How are we going to choose good leaders when a gunman robs us off our democratic rights. We don't want guns to rule this nation. Justice must prevail if we are to have good leaders.

One wonders why no armed security personnel were stationed at Tole in 2007 when it was common knowledge that guns had affected polling at Tole in previous elections. 
At Tumbilyam supporters of the local candidate came and took the box at gunpoint. The presiding officer was offered K250 if he would present the box for counting but he refused, so that box was 'lost' and was never presented at the counting centre.

The box for Ainumanda was brought to Wakumare (Wabag Secondary School) because of fighting in the gazetted place. A candidate suspecting foul play brought security personnel who arrested the polling officials. The box was then taken to Wabag for polling, but after only 50 votes had been cast officials closed the polling after a commotion when it became apparent that anybody was able to come and vote there, not just people from Ainumanda.

The electoral roll caused confusion in many places with whole families and subclans missing. Many of these people claimed to have given their names for the new roll and were incensed when the Electoral Commission claimed that it was their fault that their names did not appear on the roll. In some places, such as Maramuni, the roll was not used at all.

In the Wabag electorate the returning officer used a method whereby several boxes shared the one ward-level electoral roll. These were referred to as 'split' boxes (more correctly it would be a 'split roll'). Thus, for one ward there might be two or even three boxes positioned in different places within a ward, catering for people from different clans or hauslain. The returning officer claimed that this was fairer for smaller clans to vote separately rather than risk being intimidated by a larger and more powerful clan. There were 16 'split' boxes in the Wabag Open electorate. The idea has its merits, but does open up the risk of double voting. When it came time for counting, 'split' boxes from the same ward were opened and counted together as if they came from one box or one polling place.

\section{Use of the roll}

Use of the rolls varied. In some places the names were called from the roll and a person answering to that name would go into the enclosure to collect voting papers. In other places names were not called, but simply marked off as people entered the polling enclosure. In other places names of a 'family' would be called and a small group would come to collect the papers for the whole family. In some places the roll was not used at all; in this case the roll merely served as a licence to receive a certain number of ballot papers.

Table 18.7 in the appendix at the end of this chapter shows the number of papers issued according to the roll, along with the number of marked papers returned for counting. An excess of papers presented for counting is regarded by the returning officer as a 'miscount' when papers were distributed in the 
pre-polling preparations the night before polling began. For the Wabag Open electorate there was no miscount greater than +8 , indicating that boxes were not 'stuffed' with more papers than were allowed for that box.

There was some under-age voting, but this was not common, particularly when there was 'family' or 'clan' voting. With such voting a few senior family members collect and fill in voting papers for all the family members on the roll and there is no way of knowing if the name of the person called from the roll is underage, a 'ghost', or not present at all.

In many polling places fingers were not marked with ink and there appeared to be little attempt to prevent double or multiple voting. One woman told us that she had voted 25 times by going to get voting papers when names of people who were underage or absent were called.

\section{Polling and limited preferential voting}

The LPV system was generally ignored in Enga in 2007. In the Wabag Open electorate, the 2004 by-election, using LPV, was essentially a race between two candidates, where the winner was leading all the way. In that by-election people did not see how LPV could affect the outcome of the elections. In the 2007 election, most people were concerned only for their first choice and demonstrated little concern for the second and third choices. Sam Tei Abal was the favourite and many people thought that he could not be eliminated, so why bother about the other preferences? In this case, their prediction was right.

Some election awareness had been conducted in the province, mostly by civil society groups at schools and churches. People were shown an example of a voting paper and told that they would have three preferences, but it appeared that the awareness had little influence on the majority of the Enga populace with their strongly held practice of group voting for certain prominent candidates. Because of the group voting practice it is unclear whether LPV allowed women more freedom to vote.

How then did those marking papers choose the second and third preferences? Our team asked 10 people at each polling place and received a number of different responses. Some chose 'hot' candidates so that at least one of their choices would win. Some chose candidates who they were sure would lose so that the second and third choices would not possibly support a candidate who might compete seriously with the candidate of their first choice. Others said that they simply looked at the poster with the names and numbers of candidates and selected the second and third preferences at random. In a few cases, people traded second or third preferences as political credit for future alliances. Some 
traded second or third preferences for money. One man who had been chosen to fill in all the papers for his clan said: 'I was so worried about first preference [I] didn't care much about the second and third preferences'.

A woman who filled in many ballot papers said, 'I was very conscious and careful when I distributed the second and third preferences. If I gave the second and third preferences to the 'hot candidates' then it was like I was supporting them too and my first preferences would be a total waste. So what I did was that I had distributed the second and third preferences to the weak candidates. I did that purposely so that the weak candidates would be the first ones to be eliminated and my second and third preferences would become waste'.

One person added, 'This system is giving weak candidates chances to pick up during the counting process. It's really hurting the ones who were in the lead'.

In the minority of locations where people did actually vote, there were usually several helpers in the polling places and some would check all ballot papers before they went into the ballot box, perhaps checking for formality but also the direction of both votes and preferences.

Comments by observers include the following:

- Supporters were given ballot papers by family reps to mark. Women and older people had no chance of voting.

- A wife of a certain regional candidate grabbed some ballot papers and marked them for her husband. The son came in later and did the same.

- Children voted in the parents' names. Parents were too late to collect or mark ballot papers. Officials ignored the older voters.

- A family I know well voted in three different polling places in two different electorates.

- The polling officials had no control over the entire polling. They were forced to sit and sign the ballot papers.

- To gain more votes, those who updated the common roll listed names of inlaws, cousins, ex-wives and deceased friends.

- Voters who seemed unsure were asked if they could accept money.

- A supporter said to voters in a whisper that anyone who has no choices of voting should see him.

- An old man only gave his first preference to a scrutineer to mark. When asked why, he replied, 'There was a fight about to erupt and I was scared!'

Someone said, 'The LPV system is good but it's anybody's game! Anyone could win and this would create problems for us supporters if we have given first preferences to someone else. 
Perhaps the most telling comment heard was the following: 'I did not practice my democratic rights. Someone else did on my behalf!'

\section{Women and polling}

In the 2007 polling, there were supposed to be separate voting compartments for women, with women helpers (2007 General Election Bulletin No. 8). One would think that this would be culturally acceptable in Enga considering the separation of the sexes in many aspects of life, including in church. However, it seems that cultural separation does not count when it comes to the public realm and sharing power, so there was no separate voting of men and women in Enga. We observed one polling place with notices showing separate voting compartments for women, but this was not followed in practice. The rest of the notices remained in their original cartons in the Electoral Commission office in Wabag.

Rights of women and gender issues were non-issues in the Enga elections. There were three women candidates in the province. At rallies, women were relied on for cooking food and for offering hospitality to those who came. Sometimes they would lead in singing. An Engan woman from Wabag wrote:

In most polling areas women have never voted themselves. When will the separate polling for women and men take place? We the females want to mark our leaders with our two fingers. I am frustrated to learn that separate polling never took place.

Another woman commented:

I am an LPV advocator in the province. I was proudly telling the female participants that we will have separate polling area for men and women. I am very sad that this never happened. When will this country start to recognize the potential of women? They think politics is men's game and women have no part to play ... There is an Enga saying: yana kuli nakandenge, mena kuli nakandenge, meaning you don't see dogs or pigs bones. This is applied to women. The figurative meaning is that pigs and dogs have no history in the community. When they die that's the end of them. Women are regarded as pigs' bones and dogs' bones because when they get married, they leave and go away to develop their husband's place. With this mentality, they reckon women are unfit in the decision making body ...

In this current election, very few of the females voted without intimidation. Most of us never voted through a democratic process. 
The big men have taken our rights away completely. The informal rate will be very low because certain individuals marked the papers. This is injustice to the female community. As a mother, I am very concerned for where my son's future lies. Are the leaders driving this nation in the right direction? I hope the leaders are not acting the Titanic movie in PNG.

\section{Counting}

During the counting there was a problem with crossover voting - that is, people mixing the candidate numbers from open seats and provincial seats, writing the numbers or names of provincial candidates on open ballot papers and vice versa. This contributed to most of the informal papers. It is not obvious unless the voter writes names from the 'wrong' list or the numbers are obviously not valid numbers for that seat. It would help if voting papers for provincial and open seats were in obviously different colours. Despite the crossover voting, the number of informal votes was very low (293 informal votes from 44,673 votes cast in the whole electorate [0.7 percent]), perhaps reflecting the manner of group voting done by just a few experienced people. It is notable that from the isolated Maramuni there are some boxes with no informal votes at all.

Counting for the Wabag Open electorate went quickly and relatively calmly. There was tension and a lot of delays with disputed boxes in other electorates. The way the disputes were dealt with - in many cases, telling them to take the case to the Court of Disputed Returns - left many people with a feeling that bold candidates and their supporters can get away with hijacking or tampering with ballot boxes; this may adversely affect the next election.

After counting and notification of the results, in most cases people are able to see which group voted for whom and this has consequences, both immediate and long term. A doctor at Wabag Hospital, when confronted by election-related casualties coming in for treatment, commented:

Probably after the counting we might have some casualties because some people claimed to be supporters and not have cast their votes. Moreover, they are not just counting the ballot boxes but stating the names of the places where voting took place. So then the candidates would know exactly where the votes are coming from. And if they know that they are going to get certain votes from some area, and if they don't get those votes as they have used a lot of resources on campaign, that is when trouble will actually come (Dr William Waro, Wabag Hospital, 13 July 2007). 


\section{Distribution of preferences}

Table 18.3 shows how preferences were distributed during the exclusions for the Wabag Open electorate in 2007. ${ }^{2}$ Entries of particular interest are shown in bold. In the seventh exclusion only 21 percent of preferences went to the top three candidates. That eight preferences (17 percent of the preferences) went to Marinki is understandable as both Perano and Marinki are from Maramuni. However, the 12 preferences (26 percent) that went to Samuel Kopamo, and a further 11 (24 percent) to Jonnes Kuringin are more difficult to explain.

The fact that the majority of Kyangali's preferences (tenth exclusion) went to Potane is probably because he comes from Birip which has close alliances with Potane's base vote area. Besides, Kyangali's candidature helped to split votes to disadvantage Abal.

The majority of Samuel Kopamo's preferences (twelfth exclusion) went to Daniel Kapi. They are from the same rest house. Also, despite Philip Nere's strong opposition to Daniel Kapi in the 2007 election, he used to be a manager with Kapi in the past and still has alliances with the same support base.

It is notable that 77.5 percent of the formal votes were still live at the end of the final count and one can see that the first round leaders continued to lead with the top three candidates gaining 86 percent of the preferences, indicating how the Wabag Open race was essentially a race between these three. Table 18.4 shows how over the past three elections Daniel Kapi appears to have gradually lost support (from 20 percent of the primary vote in 2002 to 13 percent in 2007), while Pato Potane has gained in popularity (from 9 percent in 2002 to 18 percent in 2007). Pato Potane also gained the most from distribution of preferences. Samuel Abel has maintained his popularity, with 24 percent of first preferences in 2002, 37 percent in 2004 (when there were only two serious contenders), and 34 percent in 2007 (when there were three principal contenders to share the first preferences). The winner won 58 percent of the live votes after exclusions, but 44.8 percent of the total valid votes. The results are summarised in Table 18.8 in the appendix of this chapter.

2 The figures for first preferences in Table 18.3 and in the appendix were taken from photos from the original tally sheets. Some figures for first preferences were changed as a result of scrutiny of votes as found in the official returns. 
Table 18.3: Distribution of preferences, Wabag Open electorate, 2007 election

\begin{tabular}{|c|c|c|c|c|c|c|c|}
\hline \multicolumn{2}{|c|}{ Exclusions } & \multirow{2}{*}{$\begin{array}{r}\begin{array}{r}\text { Primary } \\
\text { vote }\end{array} \\
1\end{array}$} & \multirow{2}{*}{$\begin{array}{r}\begin{array}{r}\text { Number of } \\
\text { preferences } \\
\text { distributed }\end{array} \\
1\end{array}$} & \multirow{2}{*}{$\begin{array}{r}\text { Abal } \\
-\end{array}$} & \multirow{2}{*}{$\begin{array}{r}\text { Potane } \\
-\end{array}$} & \multirow{2}{*}{$\begin{array}{r}\text { Kapi } \\
1\end{array}$} & \multirow{2}{*}{$\begin{array}{r}\begin{array}{r}\text { Preferences } \\
\text { going to the } \\
\text { three }(\%)\end{array} \\
100\end{array}$} \\
\hline 1 & David Kandiu Kaiti & & & & & & \\
\hline 2 & Wialo Sakatao & 5 & 5 & 2 & 2 & 1 & 100 \\
\hline 3 & Julie Daniel & 11 & 11 & 4 & 2 & - & 55 \\
\hline 4 & John Kapi & 11 & 11 & 4 & 2 & 1 & 64 \\
\hline 5 & Simon Robert & 22 & 22 & 3 & 6 & 3 & 55 \\
\hline 6 & Micros Nea Apak & 43 & 41 & 5 & 7 & 7 & 46 \\
\hline 7 & Irai Isaac Perano & 46 & 47 & 3 & 2 & 1 & 21 \\
\hline 8 & Jonnes Kuringin & 253 & 251 & 70 & 59 & 37 & 66 \\
\hline 9 & $\begin{array}{l}\text { Sakarawan Lomas } \\
\text { Samuel Tulipet }\end{array}$ & 357 & 323 & 103 & 56 & 67 & 70 \\
\hline 10 & Kandato Kyagali & 872 & 867 & 21 & 256 & 79 & 41 \\
\hline 11 & Minal Keoa Marinki & 969 & 944 & 337 & 61 & 153 & 58 \\
\hline 12 & Samuel Kopamo & 1,005 & 1,045 & 219 & 138 & 355 & 68 \\
\hline 13 & A1 Anton Wangae & 1,363 & 1,381 & 433 & 561 & 239 & 89 \\
\hline 14 & Philip Nere & 1,455 & 1,362 & 554 & 186 & 319 & 78 \\
\hline 15 & Maso Samai & 2,353 & 1,984 & 577 & 501 & 622 & 86 \\
\hline 16 & Malipu Yakali & 6,546 & 5,200 & 1,582 & 2,274 & 1,344 & 100 \\
\hline 17 & Daniel Don Kapi & 5,914 & 2,995 & 765 & 2,230 & 100 & \\
\hline 18 & Pato Potane & 8,106 & & & & & \\
\hline 19 & Samuel Tei Abal & 15,065 & & & & & \\
\hline \multirow{2}{*}{\multicolumn{3}{|c|}{ Votes gained through preferences }} & 16,490 & 4,682 & 6,343 & 3,229 & 14,254 \\
\hline & & & & $28 \%$ & $38 \%$ & $20 \%$ & $86 \%$ \\
\hline
\end{tabular}

Table 18.4: Distribution of first preferences to the top three candidates

\begin{tabular}{lrrrrrrrrrrr}
\hline & \multicolumn{2}{c}{2002} & \multicolumn{4}{c}{2004} & & \multicolumn{3}{c}{2007} \\
& & & \multicolumn{3}{c}{ First preferences } & \multicolumn{2}{c}{ Final count } & \multicolumn{2}{c}{ First preferences } & \multicolumn{2}{c}{ Final count } \\
& Votes & $\%$ & Votes & $\%$ & Votes & $\%$ & Votes & $\%$ & Votes & $\%$ \\
\hline Abal & 12,438 & 24.7 & 20,230 & 37.9 & 25,754 & 53.2 & 15,065 & 33.9 & 19,939 & 58.0 \\
Potane & 4,438 & 8.8 & - & - & - & - & 8,106 & 18.3 & 14,449 & 42.0 \\
Kapi & 10,234 & 20.3 & 15,922 & 29.8 & 22,661 & 46.8 & 5,914 & 13.3 & - & - \\
Total & 27,110 & 53.8 & 36,152 & 67.7 & 48,415 & 100.0 & 29,085 & 65.5 & 34,388 & 100.0 \\
\hline
\end{tabular}




\section{Factors influencing voting patterns}

Table 18.5 details some voting patterns in the Wabag Open electorate. A selection of seven of the 66 polling places is included here.

The seven polling places illustrate trends occurring throughout the electorate. One may see how people show solidarity in voting for certain candidates and also how they divide their votes to keep candidates and their supporters happy and to ensure their (the voters') security. The following five factors emerge as the most significant factors influencing voting patterns:

- Base vote. The candidate identifies with this place, and people consider him as 'their' candidate (see Aipanda and Teremanda).

- Clan and tribal alliances. This might rely on traditional links such as blood ties or exchange of valuables, but may also include modern features such as fighting men with guns or public servants with influential jobs and regular salaries (see Rakamanda and Imi).

- Intermarriage and relatives, either through men such as a brother and his relations through marriage, or through women such as one's mother, sister or wife and their family (see Sopas, Lakayoko, and Teremanda).

- Cash or projects - for roadwork, schools, health facilities. The link then is through the councillor who exerts influence on the voters of his ward (see Sopas and Kaiap).

- Alliances with an influential person, for example with Governor Peter Ipatas, former Member Sir Albert Kipalan, or leading businessmen (see Teremanda).

Other factors influencing voting patterns include the following:

- Party influence (for example, the NA had a strong positive influence at Kaiap and a negative influence at Tumbilyam).

- Compensation - where a candidate has assisted with compensation to settle inter-clan violence, people feel an obligation towards that candidate. (See Sopas, Rakamanda and Pasalagus above).

- Violence, real or potential (see Tumbilyam and Kaiap above).

- 'Tanim tebol' - where leaders agree to give all the votes or almost all the votes to one candidate (see Aipanda and Pasalagus above). 
Table 18.5: Results from Wabag Open electorate with possible reasons for voter choice

\begin{tabular}{|c|c|c|c|c|}
\hline Polling station & Roll & $\begin{array}{l}\text { Votes } \\
\text { allowed }\end{array}$ & $\begin{array}{l}\text { Major } \\
\text { recipients }\end{array}$ & Comments \\
\hline \multirow{3}{*}{$\begin{array}{l}\text { Aipanda } \\
\text { Tumbilyam }\end{array}$} & \multirow[t]{3}{*}{1462} & \multirow{3}{*}{$\begin{array}{l}950 \\
512\end{array}$} & \multirow{3}{*}{$\begin{array}{l}\text { Yakali } 508 \\
\text { Nere } 3\end{array}$} & Yakali is from Aipanda. \\
\hline & & & & $\begin{array}{l}\text { The Tumbilyam box went missing when } \\
\text { the polling team was attacked by Yakale's } \\
\text { supporters. The Councillor at Tumbilyam } \\
\text { is pro Sam Abal due to NA party links. }\end{array}$ \\
\hline & & & & $\begin{array}{l}\text { Philip Nere has some relatives living at } \\
\text { Tumbilyam. }\end{array}$ \\
\hline \multirow{4}{*}{$\begin{array}{l}\text { Sopas } \\
\text { Lakayoko }\end{array}$} & \multirow[t]{4}{*}{970} & \multirow{4}{*}{$\begin{array}{l}630 \\
340\end{array}$} & \multirow{4}{*}{$\begin{array}{l}\text { Abal } 259 \\
\text { Samai } 218 \\
\text { Kapi } 112\end{array}$} & Abal had contributed a large sum of \\
\hline & & & & $\begin{array}{l}\text { money from his District Support Grant } \\
\text { funds for renovation and re-opening } \\
\text { of Sopas Hospital. He also promised } \\
\text { compensation for a man who had been } \\
\text { killed in } 2002 \text {. }\end{array}$ \\
\hline & & & & $\begin{array}{l}\text { Samai is from nearby Kiwi, but from the } \\
\text { same big-tribe Malipini and his second } \\
\text { wife is from Sopas. }\end{array}$ \\
\hline & & & & $\begin{array}{l}\text { Kapi had many strong supporters from } \\
\text { earlier times. His sister is married at } \\
\text { Lakayoko, which is in the same council } \\
\text { ward as Sopas. }\end{array}$ \\
\hline \multirow[t]{3}{*}{ Kaiap } & \multirow[t]{3}{*}{976} & & \multirow[t]{3}{*}{$\begin{array}{l}\text { Abal } 720 \\
\text { Kapi } 108 \\
\text { Potane } 87\end{array}$} & $\begin{array}{l}\text { Abal is an NA candidate and the councillor } \\
\text { from Kaiap is NA party president in the } \\
\text { province. Abal also gave funds from the } \\
\text { District Roads Improvement Program } \\
\text { to the councillor to distribute to the } \\
\text { Kaimanawan people at Kaiap. }\end{array}$ \\
\hline & & & & $\begin{array}{l}\text { Kapi has family ties and students gave } \\
\text { votes to secure their road as they have } \\
\text { to pass through Kapi's territory to go to } \\
\text { school. }\end{array}$ \\
\hline & & & & $\begin{array}{l}\text { Potane's wife's grandmother is from } \\
\text { Kaiap. }\end{array}$ \\
\hline \multirow{4}{*}{$\begin{array}{l}\text { Teremanda } \\
\text {-Yaumanda } \\
\text {-Lepetenges } \\
\text {-Kwimas }\end{array}$} & \multirow[t]{4}{*}{2441} & \multirow[b]{2}{*}{947} & \multirow{4}{*}{$\begin{array}{l}\text { Nere } 798 \\
\text { Abal } 720 \\
\text { Kapi } 336\end{array}$} & Nere is from here (Yaumanda and \\
\hline & & & & Taitengis). \\
\hline & & 548 & & $\begin{array}{l}\text { Abal has strong ties with influential men } \\
\text { Roy Kipalan and Salan Ere (Kwimas). }\end{array}$ \\
\hline & & 946 & & $\begin{array}{l}\text { Kapi's mother is from here. The } \\
\text { governor's mother comes from here as } \\
\text { she is Kapi's mother's sister. }\end{array}$ \\
\hline \multirow[t]{3}{*}{ Rakamanda } & \multirow[t]{3}{*}{598} & & $\begin{array}{l}\text { Potane } 284 \\
\text { Abal } 252 \\
\text { Yakali } 22\end{array}$ & $\begin{array}{l}\text { Potane is from the neighbouring Paliu clan. } \\
\text { Refugees from a tribal fight at Rakamanda } \\
\text { have been staying with Potane's clan. }\end{array}$ \\
\hline & & & & $\begin{array}{l}\text { Abal played a part in bringing peace to } \\
\text { the area and assisted with compensation } \\
\text { payments. }\end{array}$ \\
\hline & & & & Yakali's brother is married at Rakamanda. \\
\hline
\end{tabular}




\begin{tabular}{|c|c|c|c|c|}
\hline Polling station & Roll & $\begin{array}{l}\text { Votes } \\
\text { allowed }\end{array}$ & $\begin{array}{l}\text { Major } \\
\text { recipients }\end{array}$ & Comments \\
\hline Imi & \multirow[t]{4}{*}{899} & \multirow{4}{*}{$\begin{array}{l}495 \\
404\end{array}$} & Potane 461 & \multirow{2}{*}{$\begin{array}{l}\text { Potane's clan (Paliu) and the Lyipini clan } \\
\text { border each other at Makapumanda. Pato } \\
\text { Potane's grandmother comes from here. }\end{array}$} \\
\hline -Naputes & & & Abal 163 & \\
\hline \multirow[t]{2}{*}{-Makapumanda } & & & Kapi 85 & $\begin{array}{l}\text { Abal helped with road maintenance on the } \\
\text { Wee- Naputesa road. }\end{array}$ \\
\hline & & & & $\begin{array}{l}\text { This used to be a Kapi stronghold after he } \\
\text { helped build a bridge here during the time } \\
\text { when he was member of parliament. }\end{array}$ \\
\hline Pasalagus & 915 & & $\begin{array}{l}\text { Abal } 885 \\
\text { Potane } 13 \\
\text { Marinki } 9\end{array}$ & $\begin{array}{l}\text { Abal is said to have given a sum of money } \\
\text { to a leader of the Pasalagus community to } \\
\text { help them pay compensation for the death } \\
\text { of a health worker at Birip near Wabag, } \\
\text { killed by a person from Maramuni. Giving } \\
\text { him most of the votes was a way of } \\
\text { paying him back for his assistance. }\end{array}$ \\
\hline
\end{tabular}

Another pattern evident from the data in the appendix is seen in the number of ballot papers not used or returned. Table 18.6 gives details of the seven polling places where significant numbers of papers were lost or destroyed. It shows a definite improvement over 2002, when 13 boxes were either destroyed or disputed and not counted. However, it still shows evidence of problems due to thuggery, violence or potential violence at the polls.

\section{Table 18.6: Polling places where large numbers of papers were lost or destroyed}

\begin{tabular}{|c|c|c|c|}
\hline $\begin{array}{l}\text { Polling } \\
\text { station }\end{array}$ & Place & $\begin{array}{l}\text { Number of } \\
\text { papers lost } \\
\text { or destroyed }\end{array}$ & Explanation \\
\hline 2 & Tumbilyam & 950 & $\begin{array}{l}\text { The box was hijacked by the supporters of one } \\
\text { particular candidate. The polling officer would not } \\
\text { accept a bribe and the box was never returned for } \\
\text { scrutiny. }\end{array}$ \\
\hline 17 & Taitengis & 324 & $\begin{array}{l}\text { There was a commotion because some people } \\
\text { wanted to give regional votes to one particular } \\
\text { candidate. Because of the tension, electoral officials } \\
\text { ended polling prematurely and destroyed the } \\
\text { remaining papers. }\end{array}$ \\
\hline 19 & Sakalis & 257 & $\begin{array}{l}\text { The box was accidentally exchanged with the } \\
\text { Sangurap box resulting in Sakalis having extra } \\
\text { papers. (The presiding officer at Sakalis sent the } \\
\text { leftover papers back with the polling box and they } \\
\text { were burned in front of the counting centre.) }\end{array}$ \\
\hline 22 & Lenki & 211 & $\begin{array}{l}\text { Time ran out and it was getting dark at Lenki so the } \\
\text { unused papers were burned at the polling booth in } \\
\text { the presence of security personnel. }\end{array}$ \\
\hline 23 & Ainumanda & 455 & $\begin{array}{l}\text { Due to an ongoing tribal conflict at Ainumanda, the } \\
\text { box was brought to Wabag Secondary School at } \\
\text { Wakumare. Security personnel assumed the box had } \\
\text { been hijacked and after arresting the election officials } \\
\text { brought the box to Wabag. Voting in Wabag the next } \\
\text { day ended prematurely after a commotion erupted } \\
\text { and ballot papers, tables and chairs were damaged or } \\
\text { destroyed. }\end{array}$ \\
\hline
\end{tabular}




\begin{tabular}{clcl}
\hline $\begin{array}{c}\text { Polling } \\
\text { station }\end{array}$ & Place & $\begin{array}{c}\text { Number of } \\
\text { papers lost } \\
\text { or destroyed }\end{array}$ & Explanation \\
\hline 28 & Birip & 391 & $\begin{array}{l}\text { Ballot papers were burned because the supporters of } \\
\text { a candidate from the area wanted to take and mark } \\
\text { the papers. }\end{array}$ \\
\hline 37 & $\begin{array}{l}\text { Premier Hill } \\
\text { and Hidden } \\
\text { Valley }\end{array}$ & 116 & $\begin{array}{l}\text { Ballot papers were burned because of a commotion } \\
\text { in which supporters of regional candidates demanded } \\
\text { that votes go to their candidates instead of giving } \\
\text { people a choice. }\end{array}$ \\
\hline
\end{tabular}

These are the places where there was official notification of papers being lost or destroyed. The writer observed one polling place where 100 papers were left after everyone had voted and leaders, in the presence of security personnel, dealt out those papers, which were marked for the candidate of their choice.

\section{Implications}

How did the LPV system function in the 2007 election, and what are the implications for democracy in Enga? I have noted above that there was little effective awareness provided about the LPV system, but more significantly there was even less political will among public servants and community leaders that such awareness take place. Some people voted as individuals (though not in secret). Most voted in groups: as family groups, or even as clan groups. Political parties had an influence, but generally people dealt out their votes with the prime consideration being the wellbeing of their clan. Moreover, in the Wabag Open electorate the focus was on first preferences with little importance given to second and third preferences.

The focus on first preferences emerges from an Enga political culture which relies on the patronage of an influential 'bigman' who can attract projects and bring services to the area. Thus, campaign strategies in Enga extend over the five years between elections and are not limited to the few weeks of official campaigning prior to polling. Elections are a form of investment, with successful candidates rewarding their supporters and disregarding others. This is the importance of strategic alliances. Money, guns, and employment in both the public and private sectors contribute to both continuities and innovations on the traditional Enga systems of forming alliances, particularly for warfare and for the tee pig exchange. The LPV system may provide new avenues for forming alliances, and linking voters and candidates; however, this is still at an early stage, and the traditional bigman system still predominates.

The system that is emerging has distinct disadvantages. Attempts to establish bloc voting within a clan can provoke anger within the community. Winners will 
often favour supportive clans by funding their projects and providing services to their area while others miss out. Relationships soured during the elections do not mend easily. We are not aware of anyone having died in election-related violence in the Wabag electorate. However, at least five people have died in election-related violence in the adjacent Ambum-Kompiam electorate. The lack of post-election tribal conflict in the Wabag electorate is an indication that the election result was generally accepted.

Can we call such a system democratic? Democratic principles call for freedom of the individual to vote and, to ensure this, some form of confidentiality. A considerable number of people in Enga had no freedom to vote because others voted in their place, and it seems that there was little confidentiality, if any.

\section{Conclusion}

Compared with the 2002 election, Enga in 2007 experienced relatively peaceful voting, largely due to the presence of over 1200 security personnel. In some cases there was community-based calm. In other places the apparent 'law and order' was more a form of control under a new form of gunpoint democracy (with the guns in the hands of the security forces).

Enga political culture is managing the LPV system by importing it into a political culture where there is little individual freedom of choice, limited freedom to vote for women, and where the confidentiality of individual voters' choices is not available to the majority of voters.

For the situation to change, some hard issues will have to be faced. There is an urgent need to improve the electoral roll. There is also a need to convince people that everyone has a right to vote and that group voting has serious disadvantages. Also, there must be checks to counter political patronage and cronyism at all levels of the provincial administration, and better ways to deal with disputed returns so that justice may be done but also be seen to be done. These issues should not be taken in isolation but treated in an integrated way. 


\section{References}

Gibbs, P., 2004. 'Democracy and Enga political culture', in P. Gibbs, N. Haley and A. McLeod, 'Politicking and voting in the highlands: the 2002 Papua New Guinea elections'. State, Society and Governance in Melanesia Discussion Paper 2004/1. Canberra: State, Society and Governance in Melanesia Program, The Australian National University, pp. 2-15.

Gibbs, P., 2006. 'Limited preferential voting and Enga political culture', Catalyst 36(1):3-25.

Gibbs, P. and Lakane, J., 2003. 'Haves and have-nots: the 2002 elections in the Enga Province, $\mathrm{PNG}^{\prime}$, Catalyst 33(2):96-116.

\section{Appendix}

Table 18.7: Voting statistics for Wabag Open electorate, 2007 election

\begin{tabular}{lr}
\hline Number of registered voters & 49,633 \\
Total votes cast & 44,690 \\
Informal votes & $293 \quad$ (0.7\% of ballots) \\
Total allowable ballot papers & 44,397 \\
Total ballot papers remaining in count & 34,388 \\
Total votes distributed & 21,226 \\
Exhausted ballot papers & $10,009 \quad$ (22.5\% of allowable ballots) \\
Absolute majority $(50 \%+1)$ & 17,195 \\
\hline
\end{tabular}




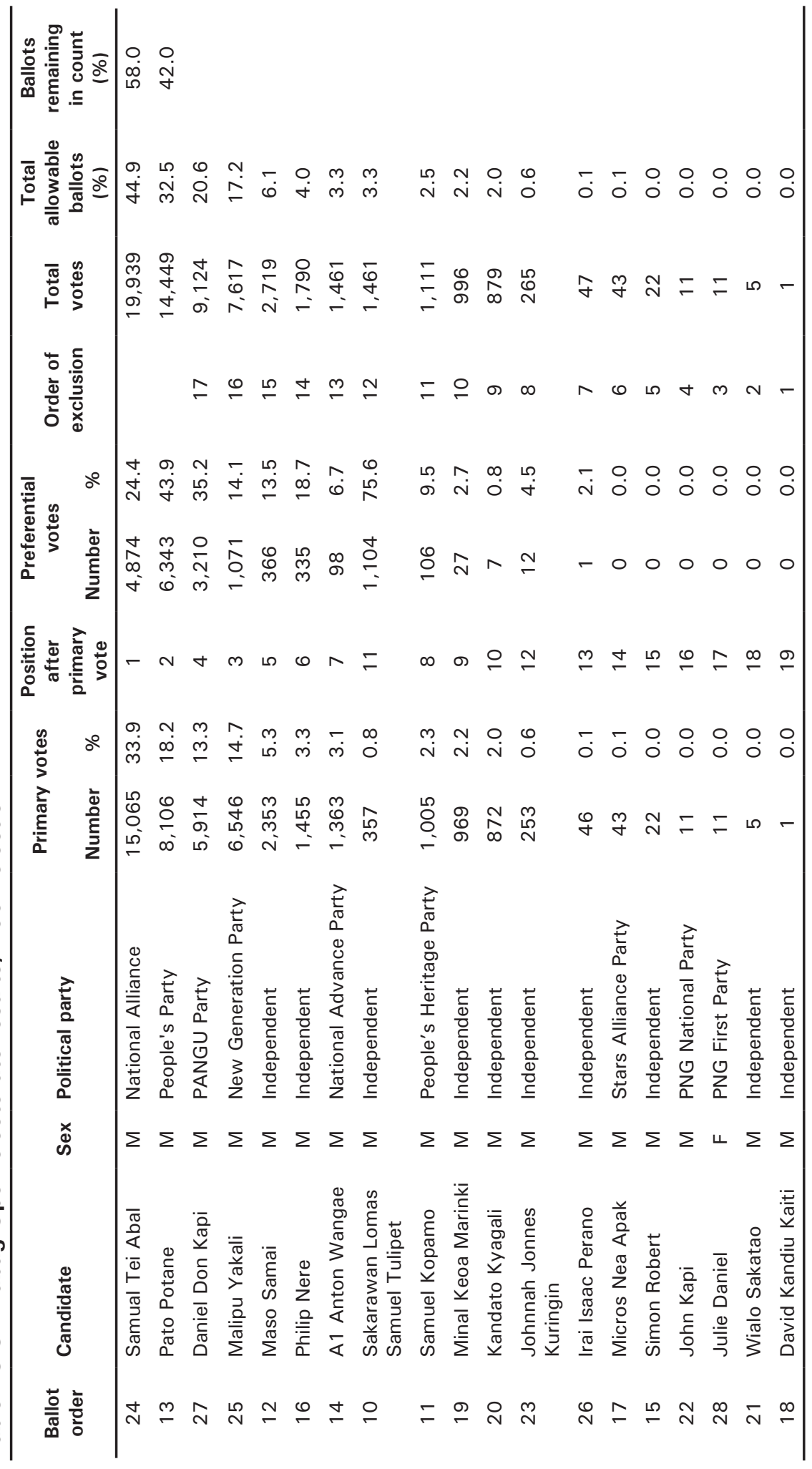


Table 18.9: Used and unused ballot papers in Wabag Open electorate, 2007 election

\begin{tabular}{|c|c|c|c|c|c|c|}
\hline Polling station & $\begin{array}{l}\text { Station } \\
\text { number }\end{array}$ & $\begin{array}{c}\text { Ballot box } \\
\text { number }\end{array}$ & $\begin{array}{l}\text { Ballots sent } \\
\text { (roll) }\end{array}$ & $\begin{array}{l}\text { Ballots } \\
\text { counted }\end{array}$ & Informal & Difference $^{a}$ \\
\hline Tukusenda & 1 & 0209 & 998 & 999 & - & +1 \\
\hline Aipanda & 2 & 0207 & 512 & 511 & 1 & -950 \\
\hline Tumbilyam & & 0208 & 950 & & & \\
\hline Tambitanis & 4 & 0206 & 949 & 944 & 5 & 0 \\
\hline Lakolama & 5 & 0205 & 1168 & 1157 & 10 & -1 \\
\hline Kubalis & 6 & 0204 & 337 & 921 & 7 & -36 \\
\hline Yakananda & & 0170 & 627 & & & \\
\hline Nandi & 7 & 0203 & 991 & 988 & 2 & +1 \\
\hline Sakarip & 8 & 0202 & 826 & 818 & 6 & -2 \\
\hline Sopas & 9 & 0201 & 630 & 959 & 3 & -8 \\
\hline Lakayoko & & 0158 & 340 & & & \\
\hline Kiwi & 10 & 0200 & 1109 & 1103 & 7 & +1 \\
\hline Kaiap & 11 & 0199 & 976 & 971 & 1 & -4 \\
\hline Kamas & 12 & 0198 & 1053 & 1031 & 7 & -15 \\
\hline Kopen & 13 & 0197 & 549 & 548 & 1 & 0 \\
\hline Sari & 14 & 0196 & 1292 & 1277 & 15 & 0 \\
\hline Tole & 15 & 0195 & 1887 & 1870 & 17 & 0 \\
\hline $\begin{array}{l}\text { Yaumanda, } \\
\text { Lepatenges and } \\
\text { Kwimas }\end{array}$ & 16 & $\begin{array}{l}0194 \\
0167 \\
0174\end{array}$ & $\begin{array}{c}2441 \\
(947 / 548 / \\
946)\end{array}$ & 2405 & 20 & -16 \\
\hline Taitenges & 17 & 0193 & 1235 & 908 & 3 & -324 \\
\hline $\begin{array}{l}\text { Lakemanda } \\
\text { Waipu }\end{array}$ & 18 & $\begin{array}{l}0192 \\
0157\end{array}$ & $\begin{array}{c}1308 \\
(458 / 850)\end{array}$ & 1243 & 4 & -61 \\
\hline $\begin{array}{l}\text { Sakalis } \\
\text { Sangurap }\end{array}$ & 19 & $\begin{array}{l}0191 \\
0159\end{array}$ & $\begin{array}{c}1446 \\
(868 / 578)\end{array}$ & 1187 & 2 & -257 \\
\hline Keas & 20 & 0190 & 2015 & 2008 & 8 & +1 \\
\hline $\begin{array}{l}\text { Irelya } \\
\text { Aipus }\end{array}$ & 21 & $\begin{array}{l}0189 \\
0161\end{array}$ & $\begin{array}{c}2922 \\
(1753 / 1169)\end{array}$ & 2917 & 4 & -1 \\
\hline $\begin{array}{l}\text { Lenki and } \\
\text { Pipi }\end{array}$ & 22 & $\begin{array}{l}0188 \\
0162\end{array}$ & $\begin{array}{c}1758 \\
(914 / 844)\end{array}$ & 1544 & 3 & -211 \\
\hline Ainumanda & 23 & 0187 & 505 & 50 & - & -455 \\
\hline Rakamanda & 24 & 0186 & 598 & 596 & 3 & +1 \\
\hline $\begin{array}{l}\text { Yokomanda } \\
\text { Double Bridge }\end{array}$ & 25 & $\begin{array}{l}0185 \\
0163\end{array}$ & $\begin{array}{c}689 \\
(378 / 311)\end{array}$ & 686 & 4 & +1 \\
\hline $\begin{array}{l}\text { Imi (Naputes, } \\
\text { Makapumanda) }\end{array}$ & 26 & $\begin{array}{l}0184 \\
0164\end{array}$ & $\begin{array}{c}899 \\
(495 / 404)\end{array}$ & 894 & 2 & -3 \\
\hline $\begin{array}{l}\text { Wee and } \\
\text { Yokota }\end{array}$ & 27 & $\begin{array}{l}0183 \\
0165\end{array}$ & $\begin{array}{c}655 \\
(393 / 262)\end{array}$ & 616 & 2 & -37 \\
\hline $\begin{array}{l}\text { Birip and } \\
\text { Birip Community } \\
\text { School }\end{array}$ & 28 & $\begin{array}{l}0182 \\
0166\end{array}$ & $\begin{array}{c}2458 \\
(1229 / 1229)\end{array}$ & 2061 & 6 & -391 \\
\hline $\begin{array}{l}\text { Akom and } \\
\text { Kapamale }\end{array}$ & 29 & $\begin{array}{l}0181 \\
0169\end{array}$ & $\begin{array}{c}580 \\
(464 / 116)\end{array}$ & 577 & 3 & 0 \\
\hline
\end{tabular}


Election 2007: The Shift to Limited Preferential Voting in Papua New Guinea

\begin{tabular}{|c|c|c|c|c|c|c|}
\hline Polling station & $\begin{array}{l}\text { Station } \\
\text { number }\end{array}$ & $\begin{array}{c}\text { Ballot box } \\
\text { number }\end{array}$ & $\begin{array}{c}\text { Ballots sent } \\
\text { (roll) }\end{array}$ & $\begin{array}{l}\text { Ballots } \\
\text { counted }\end{array}$ & Informal & Difference \\
\hline Lukitap & 30 & 0180 & 773 & 769 & 5 & +1 \\
\hline $\begin{array}{l}\text { Waimalemanda } \\
\text { and Takandu }\end{array}$ & 31 & $\begin{array}{l}0179 \\
0168\end{array}$ & $\begin{array}{c}764 \\
(464 / 300)\end{array}$ & 765 & - & +1 \\
\hline Kerepusmanda & 32 & 0178 & 598 & 542 & 57 & +1 \\
\hline Yailengis (Sirunki) & 33 & 0177 & 572 & 572 & 1 & +1 \\
\hline $\begin{array}{l}\text { Beat St \& Wabag } \\
\text { 2nd }\end{array}$ & 34 & 0176 & 487 & 488 & 7 & +8 \\
\hline Police Barracks & 35 & $0175^{\mathrm{b}}$ & 407 & 333 & 2 & -72 \\
\hline $\begin{array}{l}\text { Premier Hill \& } \\
\text { Langress }\end{array}$ & 37 & 0173 & 734 & 603 & 15 & -116 \\
\hline Hidden Valley & 38 & 0172 & 329 & 329 & & \\
\hline Newtown-Aipus & 39 & 0171 & 337 & 335 & 2 & 0 \\
\hline Yakananda & 40 & 0170 & (627) & & & \\
\hline Kepamale & 41 & 0169 & (116) & & & \\
\hline Takandu & 42 & 0168 & $(464)$ & & & \\
\hline Kwimas & 43 & 0167 & (946) & & & \\
\hline Birip C. School & 44 & 0166 & (1229) & & & \\
\hline Yakota & 45 & 0165 & $(262)$ & & & \\
\hline Makepumanda & 46 & 0164 & (404) & & & \\
\hline Double Bridge & 47 & 0163 & (311) & & & \\
\hline Pipi & 48 & 0162 & (914) & & & \\
\hline Aipus & 49 & 0161 & (1169) & & & \\
\hline Waipu & 50 & 0160 & $(458)$ & & & \\
\hline Sangurap & 51 & 0159 & $(578)$ & & & \\
\hline Lakayoko & 52 & 0158 & (630) & & & \\
\hline Biako \& Pai & 53 & 0223 & $(720)$ & & & \\
\hline Pai & 54 & 0222 & (129) & & & \\
\hline Pokale Malandu & 55 & 0221 & 1128 & 1129 & 3 & +4 \\
\hline Pasalagus & 56 & 0220 & 915 & 912 & 3 & 0 \\
\hline Wailep & 57 & 0219 & 641 & 606 & 38 & +3 \\
\hline Tongori & 58 & 0218 & 436 & 436 & - & 0 \\
\hline Kaimatok & 59 & 0217 & 615 & 614 & 2 & +1 \\
\hline Wangalongen & 60 & 0216 & 481 & 482 & - & +1 \\
\hline Neliyaku & 61 & 0215 & 625 & 618 & 7 & 0 \\
\hline Ilya & 62 & 0214 & 474 & 470 & 1 & -3 \\
\hline Poreaki & 63 & 0213 & 545 & 546 & - & +1 \\
\hline Warakom & 64 & 0212 & 813 & 813 & 1 & +1 \\
\hline Penale & 65 & 0211 & 253 & 253 & 3 & +3 \\
\hline Net & 66 & 0210 & 219 & 220 & - & +1 \\
\hline
\end{tabular}

a Difference indicates the number of ballot papers lost or destroyed. 